Gut, 1964, 5, 537

\title{
Mode of action of histamine in causing gastric secretion in man
}

\author{
C. G. CLARK, V. JUNE CURNOW, J. G. MURRAY, F. O. STEPHENS, AND \\ J. H. WYLLIE ${ }^{1}$ \\ From the Departments of Surgery, University of Aberdeen, and King's College \\ Hospital Medical School, London
}

EDITORIAL SYNOPSIS The pattern of gastric secretion has been studied in a series of patients following the augmented histamine test and the insulin test. In the same patient, the amount of acid and pepsin secreted is remarkably similar following these two tests. In both, acid and pepsin secretion is inhibited to a similar degree by small doses of hexamethonium and atropine. It is concluded that the action of histamine in causing gastric secretion in man is not a specific one on the acidsecreting cells, nor does it act directly upon these cells. It is suggested that histamine acts through nerves.

The mode of action of histamine in causing gastric secretion is discussed and evidence presented that it is unlikely that this substance is the naturally occurring local chemostimulator of acid secretion in man.

Most people believe that histamine has a physiological function in the stimulation of gastric secretion. As long ago as 1938 Babkin suggested that on stimulation of the vagal nerves, acetylcholine is released which in turn releases histamine and that this substance is the final specific chemostimulator of acid secretion in the stomach. There is no doubt that there are large amounts of histamine occurring naturally in the wall of the stomach of man (Murray and Wyllie, 1964). It is clear that histamine when injected subcutaneously or given slowly by the intravenous route is a very powerful stimulus to acid secretion.

The view that histamine acts directly on acidsecreting cells is supported by the fact that even when gastric mucosa is transplanted to subcutaneous tissues, secretion can still be elicited by histamine (Ivy and Farrell, 1925; Klein, 1932; Merritt and Kelly, 1959). Although high concentrations may be necessary it will evoke secretion from isolated gastric mucosa which has been separated completely from the body and preserved in vitro by artificial fluids (Davies, 1948; Davenport and Chavré, 1950). It is interesting to note, however, that the contact of histamine with the secretory cells must be intimate and via their submucosal or deep surface rather than their mucosal or outer surface. By comparison huge quantities of histamine must be applied to the 'Medical Research Council research assistant. luminal surface of the mucosa to produce even small responses of acid (Lim, Ivy, and McCarthy, 1925).

The gastric juice produced in animals in response to histamine is rich in acid but the secretion of pepsin is variable. In dogs and cats there is good evidence that histamine preferentially stimulates acid-secreting cells and causes little, if any, pepsin secretion. There may be an initial burst of pepsin secretion but it has been argued that this represents 'washingout' of pre-formed pepsin and not a true secretion. Furthermore, this short-lived secretion of pepsin does not occur in dogs if a second injection of histamine is given (Babkin, 1930; Vineberg and Babkin, 1931; Gilman and Cowgill, 1931 ; Björkman, Norden, and Uvnäs, 1943). Most of the early investigations on the effect of histamine in man, usually with small doses of the substance, present a similar picture of gastric secretion. They indicate that the response to histamine in man results in an insignificant secretion of pepsin in comparison with that of acid. Code (1956), reviewing the subject, concluded that the predominant if not the entire secretory effect of histamine on the gastric mucosa is one of stimulation of the production of acid.

This article discusses the mode of action of histamine in stimulating gastric secretion in man and indicates that this substance is not specific in causing acid secretion but results in the secretion of 
large amounts of pepsin as well. The evidence suggests that histamine does not act directly on the acid-secreting cells but largely through stimulation of nervous tissue in the stomach.

\section{METHODS}

To test the mechanism of histamine-induced secretion, gastric secretory responses were obtained in the following circumstances: (1) every patient had a histamine test; (2) to confirm the reliability of our technique the test was repeated without modification in 23 patients; (3) to compare the actions of histamine and insulin, a series of 21 patients also had an insulin test; (4) to study the anti-secretory actions of hexamethonium and atropine 18 cases had histamine tests and six cases had insulin tests modified by the previous administration of these drugs.

SUBJECTS The subjects of these investigations were 49 men and 13 women, most of whom were under investigation immediately before operation for duodenal or gastric ulceration. Twelve patients with no history of dyspepsia, admitted to the ward for treatment of conditions such as varicose veins and hernia, volunteered to act as normal controls.

COLLECTION OF GASTRIC JUICE The patient was starved for 10 hours before each test. A Levin tube was passed through the nose into the stomach. $X$-ray screening then demonstrated that the tip of the tube was in the pyloric antrum; if not, it was manipulated into this position, and secured to prevent the tip passing on into the duodenum. The stoniach was emptied as completely as possible by hand suction and the juice was discarded. Constant machine suction (Robert's electric pump) to a negative pressure of $25 \mathrm{~cm}$. of water was then started and juice was collected in periods as described for histamine and insulin tests. During the test the patient was comfortably propped up in bed, inclining slightly to his left. He was not required to spit out saliva. Some cases were screened again at the end of the test to confirm that the collecting tube had not moved.

STORAGE OF SPECIMENS Gastric juice was stored in chemically-clean 1-pint bottles of the type used for intravenous fluids. Immediately each sample was collected it was placed in a refrigerator at $+4^{\circ} \mathrm{C}$. where it remained until the estimations were made. This was usually the next day, but in some cases was as long as four days later.

AUGMENTED HISTAMINE TEST The technique was based on that described by Kay (1953). After the stomach had been emptied as described, the test was performed as follows:

At zero time collection of the basal hour secretion was begun. At 40 minutes the patient received an intramuscular injection of $50 \mathrm{mg}$. of mepyramine maleate (Anthisan) to obviate the systemic effects of histamine. At 1 hour he received a subcutaneous injection of histamine acid phosphate $(0.04 \mathrm{mg}$. $/ \mathrm{kg}$. of body weight). Thereafter, juice was collected in 15-minute samples for one hour.
INSULIN TEST This was performed as follows:

At zero time collection of the basal hour secretion was begun. At 1 hour the patient received a subcutaneous injection of 15 units of soluble insulin, regardless of his body weight. A venous blood sample was taken just before this injection and four further samples were taken at half-hour intervals. Gastric juice was collected in four half-hour periods.

INJECTION OF DRUGS The effect on gastric secretion of the following injections, given regardless of body weight, was estimated: (1) hexamethonium iodide $25 \mathrm{mg}$; (2) atropine sulphate $0.6 \mathrm{mg}$. (1/100 gr.); (3) hexamethonium iodide $25 \mathrm{mg}$. along with atropine sulphate $0.6 \mathrm{mg}$. These were injected 15 minutes before the end of the basal hour.

In the case of multiple tests the control test was done first, and was followed by others in the order given above. These were usually done on successive days, but after atropine two days were allowed to elapse before the next test.

\section{ESTIMATIONS}

After the volume of each specimen had been noted, estimations were made on samples of gastric juice filtered through glass wool.

FREE ACID Free acid was estimated by titration of $2 \mathrm{ml}$. samples of juice with $\mathrm{N} /: 0 \mathrm{NaOH}$, using methyl orange indicator.

PEPSIN Pepsin was measured by the method of Hunt (1948) with the modification that only $0.5 \mathrm{ml}$. of acidified gastric juice was used in each test instead of $1.0 \mathrm{ml}$. Optical densities were measured on a Unicam spectrophotometer SP.500. One hundred units of pepsin by this modification is that quantity of pepsin which under the conditions of the estimation liberate an amount of tyrosine-like substance giving, with Folin and Ciocalteu's reagent, an intensity of blue colour equal to that produced by $20 \mu \mathrm{g}$. of phenol under similar conditions.

The reliability of this method of pepsin estimation was shown by the following simple experiments. In a series of 50 duplicate pepsin estimations the mean of the difference was 4.6 units $/ \mathrm{ml}$. Samples of gastric juice were also tested for peptic activity on four successive days (Table I), and it was observed that there was no loss of peptic activity during storage under these conditions.

BLOOD SUGAR This was estimated by the method of Hagedorn and Jensen (1923).

BIO-ASSAY Bio-assay of antihistaminic activity in gastric juice was performed by adding neutralized gastric juice to an $8 \mathrm{ml}$. organ bath containing guinea-pig ileum in oxygenated tyrode solution. The guinea-pig ileum was exposed to a constant dose of histamine for $15 \mathrm{sec}$. of a 75 sec. cycle. Gastric juice was added for one cycle and the ensuing inhibition was compared with the inhibitions caused by more potent and less potent doses of mepyramine maleate similarly added. 
TABLE I

PEPTIC ACTIVITY ESTIMATED ON FOUR CONSECUTIVE DAYS IN GASTRIC JUICE STORED AT $4^{\circ} \mathrm{C}$. (PEPSIN UNITS/ML.)

\begin{tabular}{crrrr} 
Sample & \multicolumn{5}{c}{ Day } & \multicolumn{1}{c}{} \\
\cline { 2 - 5 } & \multicolumn{1}{c}{$l$} & 2 & 3 & \multicolumn{1}{c}{4} \\
\hline 1 & 73 & 72 & 67 & 74 \\
2 & 100 & 105 & 101 & 107 \\
3 & 73 & 83 & 79 & 82 \\
4 & 44 & 49 & 47 & 56 \\
5 & 62 & 60 & 57 & 62 \\
6 & 63 & 62 & 60 & 61 \\
7 & 56 & 70 & 79 & 76 \\
8 & 80 & 89 & 87 & 88 \\
9 & 75 & 74 & 83 & 78 \\
10 & 112 & 101 & 100 & 100 \\
Averages & 73.8 & 67.5 & 76.0 & 78.4
\end{tabular}

RESULTS

Results of duplicate tests cannot be expected to agree exactly but it is remarkable how closely they do agree. In the following sections it is shown (1) that the methods of presenting the data give the best estimates of secretory rates, (2) that the main source of error is imperfect collection of secretions, (3) that regurgitation of intestinal contents is a minor source of error, and (4) that unexplained bias may be present in the results.

BEST ESTIMATES OF SECRETORY RATES The less variation there is between duplicate tests, the more confidence one can have in the results of a single

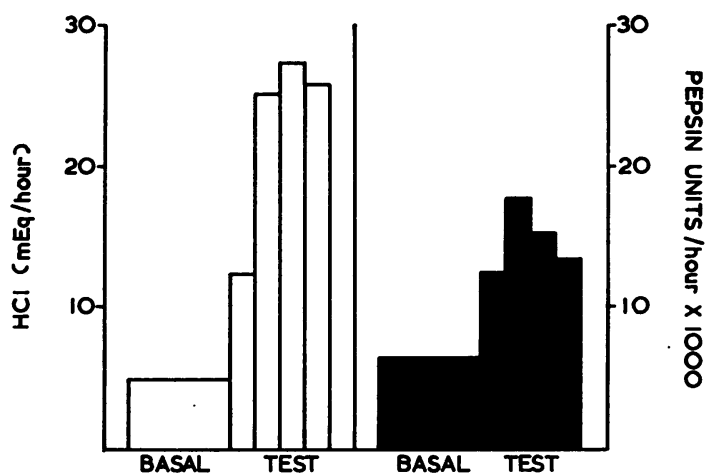

FIG. 1. Time course of acid and pepsin secretion in histamine tests. Rates of secretion in $\mathrm{mEq}$. of acid/hour and thousands of units of pepsin/hour for the basal hour and for each 15-minute collection period of the test hour. Results are average values for 55 tests.

test. The results given in this paper compare samples of gastric secretion produced in the hour following histamine administration. The maximum rate of acid secretion is not achieved immediately on injecting histamine but some 15 minutes later (Fig. 1). The results given for maximal rates of acid secretion estimated during the whole hour after histamine are therefore on average $13 \%$ less than the true maximal one-hour secretion. On the other hand the onset of pepsin secretion after histamine injection is abrupt

TA BLE II

RESULTS OF DUPLICATE HISTAMINE TESTS

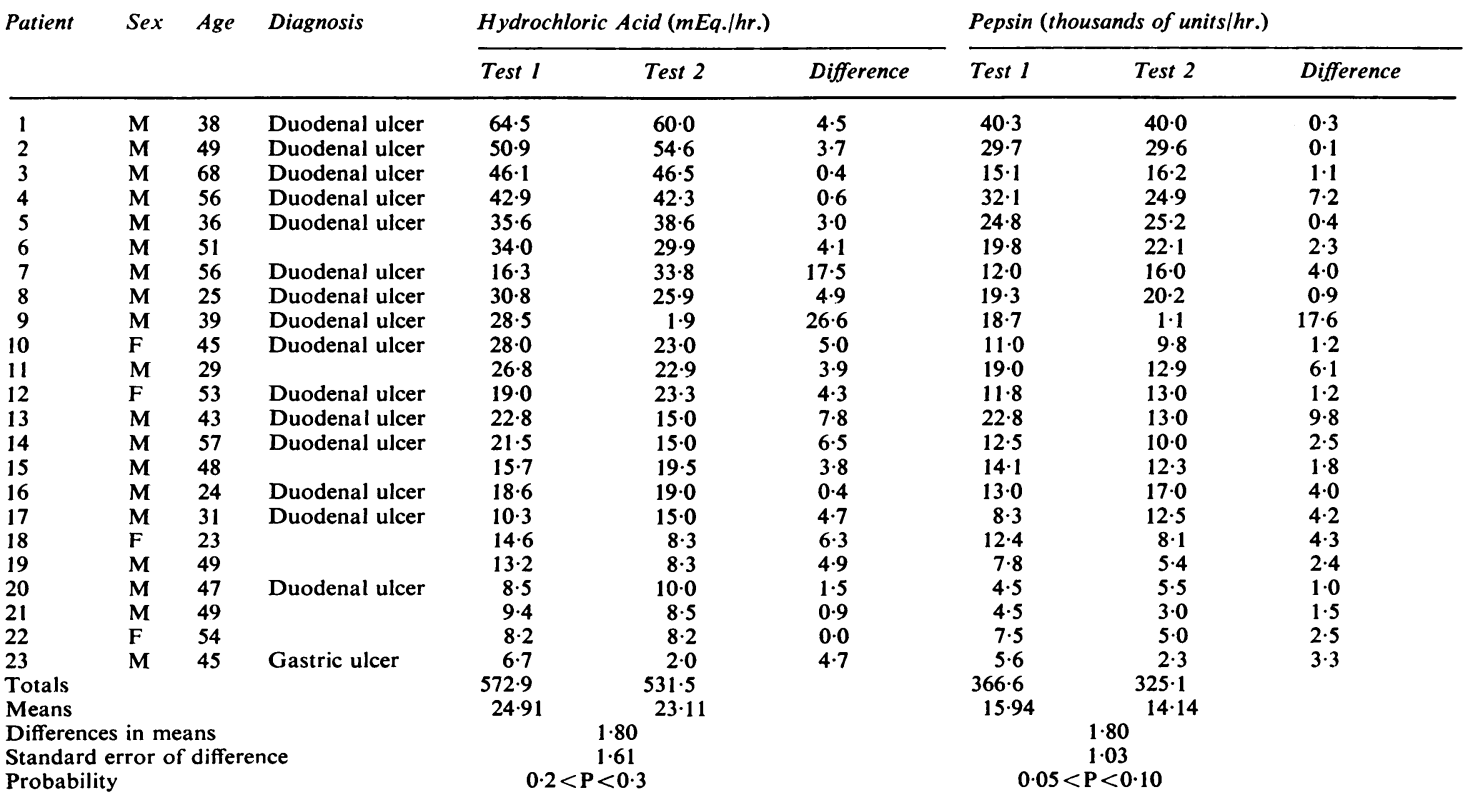


and sustained throughout the test hour. The average difference between duplicate tests based on our definition of maximal rates of acid secretion is $5.2 \mathrm{mEq}$./hour. When results based on the three last quarter-hour specimens are compared, the average difference between duplicate tests is increased by a factor of 1.7; and basing the results on the two middle quarter-hour specimens the corresponding factor is $\mathbf{3 \cdot 0}$. Some workers base their results on the secretion during the last three or the middle two 15-minute periods but it seemed better to us to base the results on the whole hour, and be content with results which are somewhat low for true maximum secretory rates.

MAIN SOURCE OF ERROR Differences between the results of duplicate tests could arise either as a result of variation in the secretory rate or as a result of incomplete collection of secretions. It is reasonable to expect the differences to be proportional to the maximal secretory rate in the former case, and independent of it in the latter.

The columns headed 'Difference' in Table II show that differences are commonly about $5 \mathrm{mEq}$. of acid per hour at both ends of the table. It will be seen that the results have been arranged in descending order of maximal acid secretory rate in the test giving the higher value. Thus it is suggested that the differences between the results of duplicate tests are independent of the secretory rate. This suggestion has been examined statistically as follows.

Since it is impossible to collect more acid than was excreted, the greater of the two test values is always the closer approximation to the true value. Accordingly the absolute differences were ranked in order of size and compared with the ranked order of the greater of the two test values. Kendall's rank correlation coefficient was calculated as a measure of the relation between the two sets of rankings. The procedure was repeated using the relative error, i.e., the ratio of the difference between pairs of determinations to the larger. The values of the correlation coefficient and the corresponding probabilities are given in Table III. This shows that there is strong evidence that the difference between two duplicate measurements is not proportional to the secretion rate.

Thus it may be concluded that the observed difference between duplicate tests (and hence the error in a single test) is due to variation in the efficiency of collection of secretion. The most suitable subjects for critical tests involving gastric secretory rates are those with high secretory capacities, an error of $5 \mathrm{mEq}$. in the high secretors being a much smaller proportion of the total secretion than a similar error in a low secretor.
TABLE III

RESULTS OF TESTS OF SIGNIFICANCE OF THE HYPOTHESIS THAT THE DIFFERENCES BETWEEN DUPLICATE RESULTS ARE INDEPENDENT OF SECRETORY RATE (ABSOLUTE DIFFERENCE) AND PROPORTIONAL TO IT (RELATIVE DIFFERENCE)

\begin{tabular}{|c|c|c|c|c|}
\hline & \multicolumn{2}{|l|}{ Acid } & \multicolumn{2}{|l|}{ Pepsin } \\
\hline & $\begin{array}{l}\text { Absolute } \\
\text { Difference }\end{array}$ & $\begin{array}{l}\text { Relative } \\
\text { Difference }\end{array}$ & $\begin{array}{l}\text { Absolute } \\
\text { Difference }\end{array}$ & $\begin{array}{l}\text { Relative } \\
\text { Difference }\end{array}$ \\
\hline $\begin{array}{l}\text { Correlation } \\
\text { coefficient } \\
\text { Probability }\end{array}$ & $\begin{array}{l}0.03 \\
0.4<P<0 .\end{array}$ & $\begin{array}{l}-0.28 \\
P=0.03\end{array}$ & $\begin{array}{l}-0.04 \\
0.6<P<0.7\end{array}$ & $\begin{array}{l}-0.35 \\
P=0.01\end{array}$ \\
\hline
\end{tabular}

REGURGITATION OF INTESTINAL CONTENTS Regurgitation of alkaline intestinal contents might vitiate the results of tests by inactivating pepsin and by neutralizing part of the acid secreted. That some regurgitation often occurs is shown by the fact that $35 \%$ of samples of gastric juice aspirated during the test hour were perceptibly bile-stained. Frequently there was only a faint greenish tinge in the juice but occasionally samples were obviously quite heavily contaminated. That this was not due to the Levin tube passing on into the duodenum was verified radiologically after the test. Thus there is no doubt about the reality of regurgitation: its possible significance was investigated as follows.

Experiments were made first in vitro. On mixing gastric juice and samples of human bile (from a T-tube draining a common bile duct) it was quickly found that bile neutralized hydrochloric acid; bile did not affect peptic activity even after 24 hours contact at $+4^{\circ} \mathrm{C}$; and the appearance of the mixture could not be used to estimate the amount of added bile. There were two reasons for this. In the first place very little difference could be detected by eye between samples containing different amounts of bile, and in the second place oxidation of bilirubin to biliverdin produced a progressive change in the colour of each sample. It is clear that in one third of the cases regurgitation of intestinal content neutralizes acid but does not affect pepsin estimation. There is no convenient method of assessing the degree of neutralization.

BIAS The statistics given at the foot of Table II indicate that there is a tendency for the results of a second test to be less than those of a first test. This tendency is not, however, statistically significant. We are unable to account for this bias.

\section{HISTAMINE CAUSES PEPSIN SECRETION IN MAN}

Impressive amounts of pepsin appear in the gastric juice of man following an injection of histamine. Figure 1 shows the way in which pepsin output rises above the basal level; the curve of pepsin output 
resembles that of acid secretion. In no case did pepsin fail to appear in increased quantities after histamine administration. These facts are most reasonably explained by supposing that pepsin is actually secreted and not merely washed out of the alveoli.

To confirm this view we compared in 23 cases the result of a maximal histamine test with that of an insulin test, because insulin is the most potent known stimulus for pepsin secretion. In 15 cases the peak acid output was in the first hour after insulin; in the others it came in the second hour. The lowest blood sugar was always recorded 30 minutes after insulin administration. The following facts were discovered: in 12 cases the acid output after insulin agreed closely with that after histamine. In these $\mathbf{1 2}$ cases insulin had induced a fall in blood sugar between 30 and $50 \mathrm{mg} . / 100 \mathrm{ml}$. In nine cases in which lesser degrees of hypoglycaemia were caused the acid output after insulin was a fraction of that after histamine, depending on the degree of hypoglycaemia induced. In two cases the acid output after insulin was only a fraction of the acid after histamine, despite adequate lowering of the blood sugar. These facts are shown in Figure 2. Thus a fall in blood sugar of 30 to $50 \mathrm{mg}$. $/ 100 \mathrm{ml}$. (regardless of the initial fasting level) evokes the maximal acid secretory response. It may be that if the blood sugar falls by much more than $50 \mathrm{mg}$. $/ 100 \mathrm{ml}$. gastric secretion is inhibited (Metys and Ronsky, 1959).

Considering now pepsin outputs in the 12 cases in which insulin caused maximal acid secretion, further facts emerge (Table IV): pepsin secretion after insulin is occasionally equal to that after histamine. More often the ratio of pepsin secretion insulin/histamine is $2 / 1$ or $3 / 2$. This ratio does not

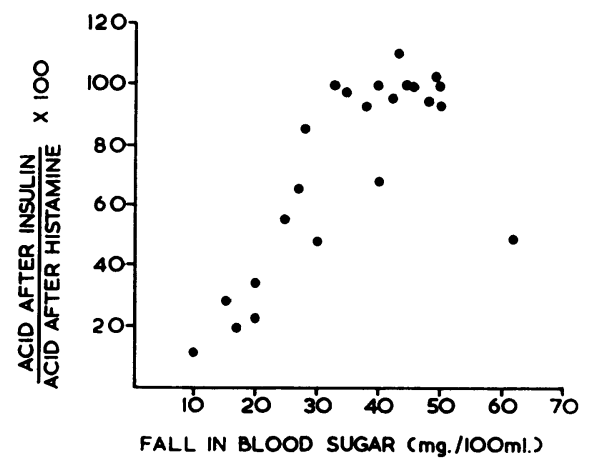

FIG. 2. The acid output after insulin is expressed as a percentage of that after histamine in the same patient and this value is plotted against the fall in blood sugar evoked by insulin. The points represent such determinations in different patients. depend on the degree of hypogylcaemia within the range of 30 to $50 \mathrm{mg} . / 100 \mathrm{ml}$. It is concluded that pepsin output after histamine is so large as to render untenable the theory that it might be a mechanical washing-out, as opposed to a genuine secretion.

TABLE IV

COMPARISON OF OUTPUT OF PEPSIN AFTER HISTAMINE AND AFTER INSULIN IN PATIENTS WHERE THE ACID OUTPUT IS THE SAME IN BOTH TESTS

\begin{tabular}{|c|c|c|c|c|c|}
\hline \multirow[t]{2}{*}{ Patient } & \multirow{2}{*}{$\begin{array}{l}\text { Fall in Blood } \\
\text { Sugar }(\mathrm{mg} . / \\
100 \mathrm{ml} .)\end{array}$} & \multicolumn{2}{|l|}{$\operatorname{Acid}(m E q)}$. & \multicolumn{2}{|c|}{$\begin{array}{l}\text { Thousands of Cinits } \\
\text { Pepsin }\end{array}$} \\
\hline & & Histamine & Insulin & Histamine & Insulin \\
\hline 1 & 35 & 13.0 & 13.4 & $13 \cdot 2$ & $24 \cdot 2$ \\
\hline 2 & 50 & 18.6 & $18 \cdot 3$ & $14 \cdot 5$ & 22.4 \\
\hline 3 & 43 & $20 \cdot 1$ & $22 \cdot 3$ & $21 \cdot 2$ & $30 \cdot 4$ \\
\hline 4 & 48 & $22 \cdot 6$ & $21 \cdot 3$ & $22 \cdot 0$ & $24 \cdot 9$ \\
\hline 5 & 45 & 25.9 & $25 \cdot 7$ & $15 \cdot 8$ & $16 \cdot 2$ \\
\hline 6 & 40 & $26 \cdot 6$ & $26 \cdot 3$ & $20 \cdot 8$ & $30 \cdot 3$ \\
\hline 7 & 50 & 30.6 & $28 \cdot 3$ & 21.9 & $35 \cdot 8$ \\
\hline 8 & 45 & $33 \cdot 2$ & $32 \cdot 8$ & $26 \cdot 5$ & $22 \cdot 1$ \\
\hline 9 & 38 & 43.4 & 39.8 & $30 \cdot 3$ & $40 \cdot 3$ \\
\hline 10 & 33 & 43.4 & $42 \cdot 8$ & $30 \cdot 3$ & $27 \cdot 2$ \\
\hline 11 & 48 & $48 \cdot 3$ & $49 \cdot 3$ & 38.5 & 50.0 \\
\hline 12 & 42 & 59.1 & 56.6 & $42 \cdot 2$ & $41 \cdot 2$ \\
\hline
\end{tabular}

It has been shown that gastric juice secreted following histamine administration contains a similar quantity of acid but less pepsin than that secreted following a suitable dose of insulin. This may be due to the fact that the dose of histamine used, though maximal for acid, was not sufficient to cause maximal pepsin secretion. However, it is also possible that mepyramine inhibits pepsin secretion although it does not inhibit acid secretion and that mepyramine inhibits the activity of pepsin in vitro (Armijo and Izquierdo, 1957). To grant either possibility places the conclusion that histamine causes pepsin secretion on an even firmer footing. With regard to the second possibility, however, mepyramine has no such action under the conditions of these experiments, as the following experiment shows.

Several samples of gastric juice were tested for antihistaminic activity on isolated guinea-pig ileum. It was found that strong antihistaminic activity appeared in the juice shortly after the injection of mepyramine. Assay carried out on one sample of juice showed antihistaminic activity equivalent to $1.0 \mu \mathrm{g} . / \mathrm{ml}$. of mepyramine maleate. This is of the order of concentration expected in the body fluids. On measuring the effect on peptic activity of adding mepyramine maleate to gastric juice it was found that no effect could be detected with less than $1.0 \mathrm{mg} . / \mathrm{ml}$. of mepyramine maleate added to the juice. At this level a $6 \%$ reduction in peptic activity was observed. At a concentration of $10.0 \mathrm{mg} . / \mathrm{ml}$. the corresponding inhibition was $22 \%$. It is clear, 
however, that the dose of mepyramine used in these tests is insufficient to have any effect on pepsin activity.

\section{ACTIONS OF HEXAMETHONIUM AND ATROPINE}

In Table $\mathrm{V}$ are shown the results of 46 tests on 18 patients. Each patient had a control test followed by one or more tests after an injection of $25 \mathrm{mg}$. hexamethonium iodide or $0.6 \mathrm{mg}$. atropine sulphate, or the two drugs together. These drugs produce a striking inhibition of histamine-stimulated gastric secretion. Probability values at the foot of Table $\mathrm{V}$ show that the observed differences are highly significant. In calculating the probabilities account has been taken of the fact that differences between duplicate tests are independent of secretion rate, and of the bias found in the results of duplicate tests. Wilcoxon's order test was used to test the significance of the differences between control and drug measurements. On an average hexamethonium reduced acid secretion to $52 \%$, atropine to $52 \%$, and the two together to $36 \%$ of the control value. The corresponding percentages for pepsin secretion are 67, 57 , and 48 . Thus we conclude that the chosen doses of hexamethonium and atropine $(25 \mathrm{mg}$. and $0.6 \mathrm{mg}$.) are approximately equivalent with regard to inhibition of histamine-stimulated gastric secretion, and that they produce about $50 \%$ inhibition. Further, the effect of both drugs together is probably greater than the effect of either alone. The data are not suitable for statistical confirmation of these latter conclusions.

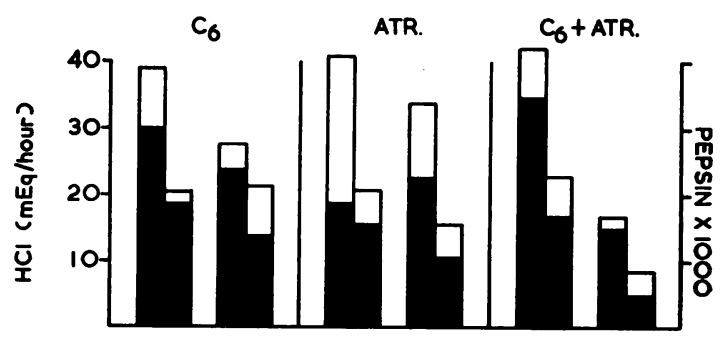

FIG. 3. Effect of hexamethonium and atropine on insulininduced secretion. The total height of the clear columns represents acid secretion and the black columns pepsin secretion. In each pair of tests the first is a control and the adjacent column the result following hexamethonium, atropine or both drugs in combination.

Hexamethonium and atropine produce a comparable reduction of acid and pepsin secretion induced by insulin hypoglycaemia. Figure 3 shows the result in six patients, each subjected to two insulin tests with adequate hypoglycaemia. During the second test, hexamethonium, atropine, or a combination was given. It appears that the inhibition of secretion by these drugs is of the same order as that observed in the histamine tests. Since the secretion after histamine resembles that after insulin (both quantitatively and qualitatively) and since atropine and hexamethonium have comparable inhibitory effects, it is possible that a common mechanism of inducing secretion is involved.

TABLE V

EFFECTS OF HEXAMETHONIUM AND ATROPINE ON GASTRIC SECRETORY RESPONSE TO HISTAMINE

\begin{tabular}{|c|c|c|c|c|c|c|c|c|c|c|c|}
\hline \multirow[t]{2}{*}{ Patient } & \multirow[t]{2}{*}{ Sex } & \multirow[t]{2}{*}{ Age } & \multirow[t]{2}{*}{ Diagnosis } & \multicolumn{4}{|c|}{ Hydrochloric Acid (mEq./hr.) } & \multicolumn{4}{|c|}{ Pepsin (thousands of units/hr.) } \\
\hline & & & & Control & $C_{8}$ & Atropine & $\begin{array}{l}C_{6} \text { and } \\
\text { Atropine }\end{array}$ & Control & $C_{8}$ & Atropine & $\begin{array}{l}C_{n} \text { and } \\
\text { Atropine }\end{array}$ \\
\hline 1 & $\mathbf{M}$ & 61 & Duodenal ulcer & $49 \cdot 5$ & $10 \cdot 8$ & $23 \cdot 5$ & $7 \cdot 2$ & $25 \cdot 5$ & 8.0 & $16 \cdot 2$ & $2 \cdot 3$ \\
\hline 2 & $\mathbf{M}$ & 59 & Duodenal ulcer & $28 \cdot 0$ & $17 \cdot 8$ & $16 \cdot 7$ & $13 \cdot 0$ & $24 \cdot 0$ & $18 \cdot 5$ & $16 \cdot 7$ & $19 \cdot 5$ \\
\hline 3 & $\mathbf{M}$ & 56 & Duodenal ulcer & $26 \cdot 5$ & $20 \cdot 6$ & $17 \cdot 0$ & $5 \cdot 2$ & $15 \cdot 1$ & $13 \cdot 5$ & $9 \cdot 3$ & 5.0 \\
\hline 4 & $\mathbf{M}$ & 46 & Duodenal ulcer & $41 \cdot 5$ & $26 \cdot 2$ & & $22 \cdot 5$ & $21 \cdot 8$ & $10 \cdot 7$ & & $17 \cdot 5$ \\
\hline 5 & $F$ & 30 & Duodenal ulcer & 22.0 & $19 \cdot 5$ & & $12 \cdot 5$ & 16.0 & $11 \cdot 0$ & & $12 \cdot 5$ \\
\hline 7 & $\mathbf{M}$ & 19 & & $22 \cdot 7$ & $6 \cdot 2$ & & & $5 \cdot 5$ & $3 \cdot 5$ & & \\
\hline 8 & $\mathbf{F}$ & 52 & Duodenal ulcer & $11 \cdot 8$ & $1 \cdot \overline{8}$ & & & $9 \cdot 7$ & 1.0 & & \\
\hline 9 & $\mathbf{M}$ & 53 & & $9 \cdot 5$ & $3 \cdot 3$ & & & $5 \cdot 7$ & 3.0 & & \\
\hline 10 & $\mathbf{M}$ & 38 & & $21 \cdot 0$ & & $14 \cdot 8$ & & $17 \cdot 5$ & & $14 \cdot 0$ & \\
\hline 11 & $\mathrm{~F}$ & 67 & & $10 \cdot 5$ & & $5 \cdot 2$ & & 6.0 & & 3.0 & \\
\hline 12 & $\mathbf{M}$ & 40 & & $7 \cdot 5$ & & $2 \cdot 5$ & & $5 \cdot 3$ & & $2 \cdot 5$ & \\
\hline 13 & $\mathbf{M}$ & 47 & Duodenal ulcer & $12 \cdot 8$ & & $2 \cdot 3$ & $7 \cdot 5$ & $9 \cdot 0$ & & 5.0 & $9 \cdot 0$ \\
\hline 14 & $\mathbf{M}$ & 34 & Duodenal ulcer & $27 \cdot 5$ & & & $8 \cdot 5$ & $24 \cdot 0$ & & & 6.7 \\
\hline 15 & $\mathbf{M}$ & 55 & Gastric ulcer & $23 \cdot 5$ & & & $4 \cdot 5$ & $15 \cdot 3$ & & & $2 \cdot 0$ \\
\hline 17 & $\mathbf{M}$ & 51 & Duodenal ulcer & $22 \cdot 1$ & & & $11 \cdot 1$ & $12 \cdot 3$ & & & $7 \cdot 1$ \\
\hline 18 & $\mathbf{M}$ & 66 & Duodenal ulcer & $14 \cdot 5$ & & & $5 \cdot 5$ & $14 \cdot 7$ & & & 3.9 \\
\hline \multicolumn{5}{|c|}{ Number of pairs of measurements } & 9 & 7 & 12 & & 9 & 7 & 12 \\
\hline \multicolumn{5}{|c|}{ Mean of control values } & $25 \cdot 11$ & $22 \cdot 26$ & $25 \cdot 4 !$ & & 14.90 & $14 \cdot 63$ & 16.66 \\
\hline \multicolumn{5}{|c|}{ Mean of values after drug } & 13.08 & $11 \cdot 72$ & $9 \cdot 21$ & & $\begin{array}{r}1470 \\
8 \cdot 80\end{array}$ & $\begin{array}{r}14.05 \\
9.53\end{array}$ & $\begin{array}{r}1000 \\
7 \cdot 78\end{array}$ \\
\hline \multicolumn{5}{|c|}{ Difference of means } & $12 \cdot 03$ & $10 \cdot 54$ & $16 \cdot 20$ & & $6 \cdot 10$ & $5 \cdot 10$ & $8 \cdot 88$ \\
\hline \multicolumn{5}{|c|}{ Probability } & 0.004 & 0.002 & $<0.001$ & & 0.032 & 0.014 & $<0.0001$ \\
\hline
\end{tabular}




\section{DISCUSSION}

For the rigorous proof that a substance is a specific local chemostimulator a number of criteria should be fulfilled and these have been discussed in the previous article (Murray and Wyllie, 1964). None of the evidence can be wholly dispensed with and its force lies in its conjunction.

The first question is whether histamine is found in the neighbourhood of acid-secreting cells and thereby likely to be released in small amounts under physiological conditions to stimulate these cells. Murray and Wyllie (1964) have discussed this problem and shown that there is not a close correlation between the distribution of naturally occurring histamine in the wall of the stomach of man and the distribution of acid-secreting cells.

Another step in the proof that an agent is the specific chemostimulator is its release during normal function. Attempts to demonstrate an increased amount of histamine in the venous effluent from the stomach have been unsuccessful. This aspect has been re-examined by Irvine, Ritchie, and Adam (1961). It is, of course, possible that the histamine escapes not into the blood but into the gastric juice. Code (1956) concluded that there was a correlation between the actual output of histamine in the gastric juice and the volume of juice secreted, and also between the outputs of histamine and hydrochloric acid. This has not been our experience when the histamine content of gastric juice was measured before and during stimulation by insulin hypoglycaemia. This showed a negative correlation between the concentration of acid and the histamine content (Wyllie, 1961). Thus, it is likely that histamine in gastric juice is correlated with some factor other than acid secretion. This view is supported by the recent experiments of Paton and Vane (1963) who showed that during electrical stimulation of nerves of the stomach only traces of histamine were liberated, and these not consistently.

Injection of the substance should mimic the physiological function. Histamine does this, and indeed the secretion resembles closely that caused by insulin hypoglycaemia. However, this does not necessarily imply that histamine is required for normal secretion: injected histamine may stimulate nerves or gland cells in an unphysiological way. The fact that histamine is effective in very low concentration does not necessarily indicate that its action is likely to be physiological. The idea that histamine has a specific stimulant action on the acid-secreting cells appears to have originated with Popielski (1920) who wrote of his experiments on dogs with gastric fistulae: 'On subcutaneous injection histamine acts powerfully in causing secretion of gastric acid, with no other effects. The secretion takes place after cutting the vagus nerves and after giving atropine; histamine most probably acts directly on the glands.' However, the results he obtained were not unambiguous. There was in fact a very marked reduction in secretion after vagotomy and after atropine.

Some of the original clinical investigators believed that histamine caused a secretion of both acid and pepsin (Matheson and Ammon, 1923; Polland and Bloomfield, 1929; Blakely and Wilkinson, 1933; Rivers, Osterberg, and Vanzant, 1936). We have shown that in man large doses of histamine injected subcutaneously result in secretion of pepsin as well as acid. The process is not simply a washing out of pepsin already formed in the glands, but a true secretion. This is in agreement with Hirschowitz, London, and Pollard (1957), who demonstrated that pepsin output in man was maintained at high levels for more than five hours during a slow infusion of histamine. Furthermore, insulia hypoglycaemia when effective produced large amounts of pepsin, and a comparison of the secretory response to insulin and histamine in the same subject showed that the amounts of acid in the two tests were almost identical. The amounts of pepsin were also similar. The time course of pepsin secreted during histamine stimulation further supported the concept of a true secretion, and these results cannot be explained by a simple washing-out theory. It is apparent that man differs from the dog and some other animals in respect of this action of histamine; in man it is not specific in stimulating acid secretion alone but is a potent stimulator of pepsin as well.

The interpretation of pharmacological investigations rests in part on the specificity of the drugs chosen. Thus, an effect which is antagonized by small doses of atropine is assumed to be mediated through the direct action of acetylcholine. Similarly an effect which is abolished by hexamethonium is assumed to be mediated through a ganglionic synapse. If histamine was the local chemostimulator of acid-secreting cells one would expect antihistamine drugs to antagonize its effect, yet it is well known that mepyramine does not inhibit the effect of histamine in causing gastric secretion. The surprising result in our experiments was that small doses of hexamethonium and atropine markedly inhibited histamine-induced gastric secretion. The amounts of acid and pepsin secreted following histamine and an effective dose of insulin are almost identical. Insulin hypoglycaemia stimulates gastric secretion through the vagus nerves. In both insulinand histamine-stimulated secretions a similar inhibition is produced by relatively small amounts of atropine or hexamethonium. This raises the possibi- 
lity that histamine, like insulin hypoglycaemia, works through nerves.

There are several possible objections to this hypothesis. First, it might be claimed that histamine induces gastric secretion by altering the blood flow in the stomach. Evidence from a recent study in dogs, however, is against this suggestion (Cumming, Haigh, Harries, and Nutt, 1963). Secondly, the inhibition of secretion by hexamethonium might be due to a reduction in gastric blood flow. We found that $25 \mathrm{mg}$. of hexamethonium only occasionally produced a detectable fall in blood pressure in the recumbent patient, and this agrees with the findings of Paton and Steinberg (1956), who used the same dose in medical students. Freis, Rose, Higgins, Kelley, Schnaper, and Johnson (1952) found that in supine subjects the hepato-portal blood flow was not significantly altered by hexamethonium. Similarly, Reynolds, Paton, Freeman, Howard, and Sherlock (1953) found that there was about a $10 \%$ fall in the splanchnic blood flow for a fall in systemic blood pressure of $10 \mathrm{~mm}$. of mercury. It is unlikely, therefore, that there is sufficient alteration in blood flow to account for the anti-secretory activity of hexamethonium. Certainly this argument cannot be used in the case of inhibition by atropine. The most direct evidence in this problem of inhibition of histamine by hexamethonium and atropine is found in the isolated stomach experiments of Paton and Vane (1963). Their work was carried out in vitro and blood flow could play no part in their findings that hexamethonium and atropine did block the effects of histamine on the stomach.

Lastly and perhaps of least importance, there is the question that if the release of histamine is closely geared to nervous activity in the stomach then do the acid-secreting cells become hypersensitive to histamine following vagal denervation? In man the reverse is true. Following vagotomy considerably less acid is secreted during an augmented histamine test; this subject has been reviewed by Payne and Kay (1962). Similarly in animals there is a depression of responses to histamine but a hypersensitivity to acetylcholine-like drugs after a nerve section (Muren, 1959). In this connexion a view about the mode of action of histamine which is sometimes held may be mentioned. It is known that acetylcholine is released during vagal stimulation and it is suggested that histamine stimulation can only be fully effective in the presence of acetylcholine. Following nerve section there is a withdrawal of a 'vagal permissive background' of acetylcholine and therefore a decrease in acid secretion on histamine stimulation. Payne and Kay (1962) have shown that the decrease in acid secretion following vagotomy during an augmented histamine test can be to a considerable extent restored by the infusion of acetyl-beta-methylcholine (Mecholyl), a drug with an acetylcholine-like action. This hypothesis is difficult of proof or disproof. It may be that the increase of acid secretion due to Mecholyl in addition to histamine is simply a reflection of the separate effects of histamine and Mecholyl added together.

How then does histamine work in causing gastric secretion or contraction of the stomach? It is clear from the work of Paton and Vane (1963) in the isolated stomach preparation that there are several different actions of histamine. Their experiments indicated that the predominant action of histamine on the isolated stomach was stimulation of cholinergic intercalated neurones in the myenteric plexus. This action could be blocked either by hexamethonium or by hyoscine. Subsidiary effects were also discovered which suggested that histamine was capable of stimulating adrenergic neurones and post-synaptic cholinergic neurones. Direct action of histamine on the effector muscle cells, was, however, of only minor importance. As one descends the gastrointestinal tract a changeover occurs, at different levels in different species, till in the terminal ileum the action is entirely direct on the muscle and hyoscine, atropine, and hexamethonium no longer have an inhibitory effect (Paton and Vane, personal communication). The present study on secretion in man supports the idea that histamine works through stimulating nerves.

The distribution of nervous tissue within the stomach has been reviewed by Agostoni, Chinnock, De Burgh Daly, and Murray (1957). When we turn to the experiments of Ivy and Farrell (1925) and Klein (1932), in which gastric mucosa had been transplanted to subcutaneous tissues but could still be stimulated to produce acid on injection of histamine, we must remember two things. First that a higher concentration of histamine was required to evoke secretion of acid. Secondly that on removal of the mucosa from the stomach it is invariable that parts of the muscularis mucosa remain with the mucosa and this contains Meissner's plexus with its ganglionic cells and nerve branches. When gastric mucosa has been separated completely from the body and preserved in vitro by artificial perfusion fluids (Davies, 1948; Davenport and Chavré, 1950) again the specimens will contain some nervous tissue (Murray and Wyllie, 1964). In both those sets of experiments it is possible that histamine caused acid secretion by stimulating nervous tissue.

The idea which has been held for so long that histamine is the specific final common chemostimulator of acid cells in the stomach has yielded little in our efforts to control gastric secretion. It seems wise to consider that histamine either has no 
physiological role in secretory activity or if it has it does so in some way different from that generally held.

The authors wish to thank Professor W. C. Wilson and Mr. H. C. Edwards for their help and encouragement. Mr. William Brass of the Department of Statistics, Aberdeen University, kindly analysed our results.

One of us (J.G.M.) is particularly indebted to the Medical Research Council for financial aid.

\section{REFERENCES}

Agostoni, E., Chinnock, J. E., De Burgh Daly, M., and Murray, J. G. (1957). Functional and histological studies of the vagus nerve and its branches to the heart, lungs and abdominal viscera in the cat. J. Physiol. (Lond.), 135, 182-205.

Armijo, M. de., and Izquierdo, M. (1957). Influencia de los antihistaminicos sobre la proteolisis por pepsina in vitro. Arch. Inst. farm. exp., Madr., 9, 182-192.

Babkin, B. P. (1930). The value of histamine as a test of gastric secretions from a physiological point of view. Canad. med. Ass. J., 23, 268-272.

(1938). The abnormal functioning of the gastric secretory mechanism as a possible factor in pathogenesis of peptic ulcer. Ibid., 38, 421-429.

Björkman, G., Norden, A., and Uvnäs, B. (1943). Histamine and peptic secretion. Acta physiol. scand., 6, 108-116.

Blakely, A. P. L., and Wilkinson, J. F. (1933). The influence of histamine and pilocarpine on the human gastric secretion. Brit. J. exp. Path., 14, 349-354.

Code, C. F. (1956). Histamine and gastric secretion. In Ciba Foundation Symposium on Histamine, edited by G. E. W. Wolstenholme and C. M. O'Connor, pp. 189-219. Churchill, London.

Cunming, J. D., Haigh, A. L., Harries, E. H. L., and Nutt, M. E. (1963). A study of gastric secretion and blood flow in the anaesthetized dog. J. Physiol. (Lond.), 168, 219-233.

Davenport, H. W., and Chavré, V. J. (1950). Conditions affecting acid secretion by mouse stomachs in vitro. Gastroenterology, 15, 467-480.

Davies, R. E. (1948). Hydrochloric acid production by isolated gastric mucosa. Biochem. J., 42, 609-621.

Freis, E. D., Rose, J. C., Higgins, T. F., Kelley, R. T., Schnaper, H. W., and Johnson, R. L. (1952). The hemodynamic effects of hexamethonium in man. J. clin. Invest., 31, 629.

Gilman, A., and Cowgill, G. R. (1931). The effects of histamine upon the secretions of gastric pepsin. Amer. J. Physiol., 97, 124-130.

Hagedorn and Jensen (1923). Method as described by Harrison, G. A. (1957) in Chemical Methods in Clinical Medicine, 4th ed., pp. 185-188., Churchill, London.

Hirschowitz, B. I., London, J. L., and Pollard, H. M. (1957). Histamine stimulation of gastric pepsin secretion in man. Gastroenterology, 32. 85-87.
Hunt, J. N. (1948). A method of estimating peptic activity in gastric contents. Biochem. J., 42, 104-109.

Irvine, W. T., Ritchie, H. D., and Adam, H. M. (1961). Histamine concentrations in the gastric venous effluent before and during acid secretion. Gastroenterology, 41, 258-263.

Ivy, A. C., and Farrell, J. I. (1925). Contributions to the physiolog: of gastric secretion. VIII. The proof of a humoral mechanism. Amer. J. Physiol., 74, 639-649.

Kay, A. W. (1953). Effect of large doses of histamine on gastric secretion of $\mathrm{HCl}$ : an augmented histamine test. Brit. med. J.. 2, 77-80.

Klein, E. (1932). Gastric secretion. II. Studies in a transplanted gastric pouch without Auerbach's plexus. Arch. Surg., 25, 442-457.

Lim, R. K. S., Ivy, A. C., and McCarthy, J. E. (1925). Contributions to the physiology of gastric secretion: I: Gastric secretion by local (mechanical and chemical) stimulation. Quart. J. exp. Physiol., 15, 13-68.

Matheson, A. R., and Ammon, S. E. (1923). Observations on the effect of histamine on the human gastric secretion. Lancet, 1. 482-483.

Metys, J., and Ronsky, R. (1959). Přispěvek k působení insulinu na žaludex̌ní sekreci u psů. [Action of insulin on gastric secretion.] Cs. gastroent. $V_{j}$.ž., 13, 95-101.

Merritt, J. W., and Kelly, W. D. (1959). Totally denervated pouches of gastric mucosa. Surgery, 46, 486-495.

Muren, A. (1959). Effect of vagotomy on the secretory responses of the Pavlov pouch to mecholyl and histamine. J. Physiol. (Lond.), 149, 70 P.

Murray, J. G., and Wyllie, J. H. (1964). The distribution of histamine and 5-hydroxytryptamine in the human stomach. Gut., 5, 530-536.

Paton, W. D. M., and Steinberg, H. (1956). A class experiment on ganglion block in human subjects. Brit. med. J., 2, 622-626.

- and Vane, J. R. (1963). An analysis of the responses of the isolated stomach to electrical stimulation and to drugs. J. Physiol. (Lond.), 165, 10-46.

Payne, R. A., and Kay, A. W. (1962). The effect of vagotomy on the maximal acid secretory response to histamine in man. Clin. Sci., 22, 373-382.

Polland, W. S., and Bloomfield, A. L. (1929). Quantitative measurements of pepsin in gastric juice before and after histamine stimulation. J. clin. Invest., 7, 57-74.

Popielski, L. (1920). $\beta$-imidazolyläthylamin und die Organextrakte. I. $\beta$-imidazolyläthylamin als mächtiger Erreger der Magendrüsen. Pflügers Arch. ges. Physiol., 178, 214-236.

Reynolds, T. B., Paton, A., Freeman, M., Howard, R., and Sherlock, S. (1953). The effect of hexamethonium bromide on splanchnic blood flow, oxygen consumption and glucose output in man. J. clin. Invest., 32, 793-800.

Rivers, A. B., Osterberg, A. E., and Vanzant, F. R. (1936). The double histamine test as an aid in the study of gastric secretory function. Amer. J. dig. Dis., 3, 12-15.

Vineberg, A. M., and Babkin, B. P. (1931). Histamine and pilocarpine in relation to the gastric secretion. Amer. J. Physiol., 97, 69-73.

Wyllie, J. H. (1961). Stomach Autopharmacology. M.D. Thesis, University of Aberdeen. 